\title{
30 Years of Ergonomics at 3M: A Case Study
}

\author{
Larson, $\mathrm{N}^{\mathrm{a},}$ and Wick, $\mathrm{H}^{\mathrm{b}}$ \\ ${ }^{a} 3 M$ Corporation, 3M Center Building224-06-W-28, St. Paul, Minnesota, 55144-1000, USA, \\ nllarson2@mmm.com,651-737-3523 \\ b3 Corporation, $3 M$ Center Building224-06-W-28, St. Paul, Minnesota, 55144-1000, USA, hwick@mmm.com, \\ 651-737-3528
}

\begin{abstract}
The added value of the Ergonomics Program at $3 \mathrm{M} \mathrm{w}$ as found to be improved employee safety, compliance with regulations and reduction of work-related illness, increases in productivity, and quality and operating efficiency. This paper describes the thirty years of existence of this program. For the first twenty years, the program objectives were to: respond to requests for a ssistance re lated to work-related musculoskeletal dis order (W MSD) concerns, $r$ aise em ployee a wareness of MSDs and ergo nomics; educate engineers in ergonomics design; and develop ergonomics teams at manufacturing locations. Since the year 2000, 3M's Ergonomics Program has been in transition from a US-centric and corporate-based technical-expertled program to a global progr am applying participatory ergonomics strategies within a macroergo nomics framework. During that transition, the ex isting program requirements were $r$ evised, new methods and program tools were created, and expectations for implementation at the manufacturing locations clarified. This paper focuses on the company's manufacturing ergonomics program activities du ring the past ten years and includes specifics of the program's objectives, risk assessment reduction process, and ergonomics technical expertise development. The main benefit achieved throughout the company is reducing employee injury while also increasing productivity and operating efficiency.
\end{abstract}

Keywords: macroergonomics, microergonomics, ergonomics programs, corp orate ergonomics, $\mathrm{p}$ articipatory ergonomics, MSD, WMSD

\section{Introduction/Background}

Most frequently the documented ju stification and purpose of a corporate ergonomics program is reduction of work related illness. However, at a very high level, the purpose and responsibility of a com pany's ergonomics p rogram is to pro tect the assets o $\mathrm{f}$ th $\mathrm{e}$ corporation, i ncluding em ployee safet $y$ and heal th, production quality an $\mathrm{d} p$ roductivity, an $\mathrm{d} t$ he co $\mathrm{m}$ pany reputation [10], with the most com mon objective $b$ eing the id entification and $m$ anagement $o f$ work-related $\mathrm{m}$ usculoskeletal disorders ( WMSDs). This pa per describes the history of the er gonomics program in a Fort une 500 Company and summarizes some benefits realized from the program results.

To identify and manage WMSDs, corporate ergonomics programs vary in design and in implementa- tion based upon business need, organizational structure and op erational objectives. However, most contain these basic program requirements[3,5,9,10]:

- Attaining management commitment

- Analyzing ergo nomics-related risk an d controlling the risk

- Developing technical expertise

- Training a nd i ncluding em ployees i $\mathrm{n}$ the program

Historically, new erg onomics p rograms first u tilize a reactive microergonomics strategy, focusing on improving a n individual em ployee's workstation in response to the em ployee de veloping and reporting symptoms of a work-related musculoskeletal disorder (WMSD). Over tim e, many co mpanies, realizing that more efficient and effective results a re realized when employees and other business partners, such as engineering, quality, and $\mathrm{m}$ anagement, are in cluded 
in id entifying and im plementing ergon omics so lutions and programs, transition to a more participatory approach [6]. Finally, some companies adopt a macroergonomics p rogram str ategy th at in cludes er go- nomics ex pertise with in co mpanywide business objectives $[5,9,10]$ (Figure 1).

\begin{tabular}{|c|c|c|c|c|c|}
\hline Strategy & $\begin{array}{c}\text { Process } \\
\text { and Scope }\end{array}$ & $\begin{array}{c}\text { Measure of } \\
\text { Success }\end{array}$ & $\begin{array}{c}\text { Core } \\
\text { Competencies }\end{array}$ & & $\begin{array}{l}\text { Organiza- } \\
\text { tional Lo- } \\
\text { cation }\end{array}$ \\
\hline $\begin{array}{l}\text { Micro- } \\
\text { ergonomics } \\
\text { Unique } \\
\text { solutions to } \\
\text { individual } \\
\text { problems. }\end{array}$ & $\begin{array}{l}\text { Assess and } \\
\text { implement } \\
\text { solutions } \\
\text { for infre- } \\
\text { quently } \\
\text { occurring } \\
\text { or unique } \\
\text { ergonomics } \\
\text { issues. } \\
\text { Often initi- } \\
\text { ated by } \\
\text { specific } \\
\text { employee } \\
\text { request or } \\
\text { need. Ef- } \\
\text { forts are } \\
\text { conducted } \\
\text { locally to } \\
\text { meet well- } \\
\text { defined } \\
\text { specific } \\
\text { need. }\end{array}$ & $\begin{array}{l}\text { Resolution } \\
\text { of individ- } \\
\text { ual's MSD } \\
\text { symptoms } \\
\text { through } \\
\text { workstation } \\
\text { redesign or } \\
\text { equipment } \\
\text { changes. } \\
\text { Success is } \\
\text { dependent } \\
\text { upon } \\
\text { knowledge } \\
\text { and skill of } \\
\text { a technical } \\
\text { expert to } \\
\text { resolve } \\
\text { ergonomics } \\
\text { issues. }\end{array}$ & $\begin{array}{l}\text {-Ergonomics Technical Expertise } \\
\text {-Training }\end{array}$ & & $\begin{array}{l}\text { Expertise } \\
\text { provided as } \\
\text { part of } \\
\text { technical } \\
\text { department } \\
\text { or contract } \\
\text { resource. }\end{array}$ \\
\hline $\begin{array}{l}\text { Participa- } \\
\text { tory } \\
\text { Ergonom- } \\
\text { ics } \\
\text { Collabora- } \\
\text { tive efforts } \\
\text { to create } \\
\text { solutions to } \\
\text { address } \\
\text { ergonomics } \\
\text { issues that } \\
\text { cross de- } \\
\text { partment } \\
\text { responsi- } \\
\text { bilities. }\end{array}$ & $\begin{array}{l}\text { Cross- } \\
\text { functional } \\
\text { teams, led } \\
\text { by techni- } \\
\text { cal experts, } \\
\text { identify } \\
\text { and im- } \\
\text { plement } \\
\text { solutions to } \\
\text { complex } \\
\text { and inter- } \\
\text { dependent } \\
\text { ergonomics } \\
\text { issues. } \\
\text { Solutions } \\
\text { focus on } \\
\text { programs, } \\
\text { training, } \\
\text { and tools. } \\
\text { Efforts are }\end{array}$ & $\begin{array}{l}\text { Establish- } \\
\text { ment or } \\
\text { revision of } \\
\text { processes, } \\
\text { jobs, or } \\
\text { programs to } \\
\text { address } \\
\text { cross- } \\
\text { functional } \\
\text { ergonomics } \\
\text { issues. Suc- } \\
\text { cess is de- } \\
\text { pendent } \\
\text { upon col- } \\
\text { laborative } \\
\text { efforts to } \\
\text { implement } \\
\text { systems and } \\
\text { processes, } \\
\text { enabling }\end{array}$ & $\begin{array}{l}\text { - Ergonomics Technical Expertise } \\
- \\
\text { Management } \\
- \\
\text { Leadership } \\
- \\
\text { Development } \\
\text { - Training }\end{array}$ & $\begin{array}{l}\text { Project } \\
\text { Collaborative } \\
\text { Program }\end{array}$ & $\begin{array}{l}\text {-Leadership } \\
\text { from a } \\
\text { business } \\
\text { or } \\
\text { technical } \\
\text { departmen } \\
\text { t. } \\
\text {-Internal or } \\
\text { contract } \\
\text { expert } \\
\text { resource. }\end{array}$ \\
\hline
\end{tabular}




\begin{tabular}{|c|c|c|c|c|}
\hline & $\begin{array}{l}\text { conducted } \\
\text { across } \\
\text { business } \\
\text { organiza- } \\
\text { tions. }\end{array}$ & $\begin{array}{l}\text { locations to } \\
\text { achieve } \\
\text { corporate- } \\
\text { wide priori- } \\
\text { tized objec- } \\
\text { tives. }\end{array}$ & & \\
\hline $\begin{array}{l}\text { Macro- } \\
\text { ergonomics } \\
\text { Strategic } \\
\text { focus using } \\
\text { ergonomics } \\
\text { to achieve } \\
\text { business } \\
\text { objectives. }\end{array}$ & $\begin{array}{l}\text { Create stra- } \\
\text { tegic pol- } \\
\text { icy, pro- } \\
\text { grams, and } \\
\text { perform- } \\
\text { ance ex- } \\
\text { pectations } \\
\text { for consis- } \\
\text { tent appli- } \\
\text { cation of } \\
\text { ergonomics } \\
\text { to support } \\
\text { business } \\
\text { objectives } \\
\text { and } \\
\text { achieve } \\
\text { confor- } \\
\text { mance to } \\
\text { internal } \\
\text { and exter- } \\
\text { nal require- } \\
\text { ments. } \\
\text { Typically } \\
\text { instituted } \\
\text { when er- } \\
\text { gonomics } \\
\text { is recog- } \\
\text { nized as an } \\
\text { integral } \\
\text { part of } \\
\text { achieving } \\
\text { business } \\
\text { objectives } \\
\text { and when } \\
\text { there are } \\
\text { efficiencies } \\
\text { to be } \\
\text { gained by }\end{array}$ & $\begin{array}{l}\text { Implemen- } \\
\text { tation of } \\
\text { sustainable, } \\
\text { effective, } \\
\text { and effi- } \\
\text { cient pol- } \\
\text { icy, pro- } \\
\text { grams and } \\
\text { standards } \\
\text { that support } \\
\text { ergonomics. } \\
\text { Success is } \\
\text { measured } \\
\text { by achieve- } \\
\text { ment of } \\
\text { corporate- } \\
\text { wide goals } \\
\text { and busi- } \\
\text { ness objec- } \\
\text { tives. }\end{array}$ & $\begin{array}{l}\text {-Strategic Planning } \\
\text {-Systems and Program Development } \\
\text {-Compliance Assurance }\end{array}$ & $\begin{array}{l}\text { Leadership, } \\
\text { from de- } \\
\text { partment } \\
\text { with global/ } \\
\text { corporate } \\
\text { responsibil- } \\
\text { ity. }\end{array}$ \\
\hline
\end{tabular}




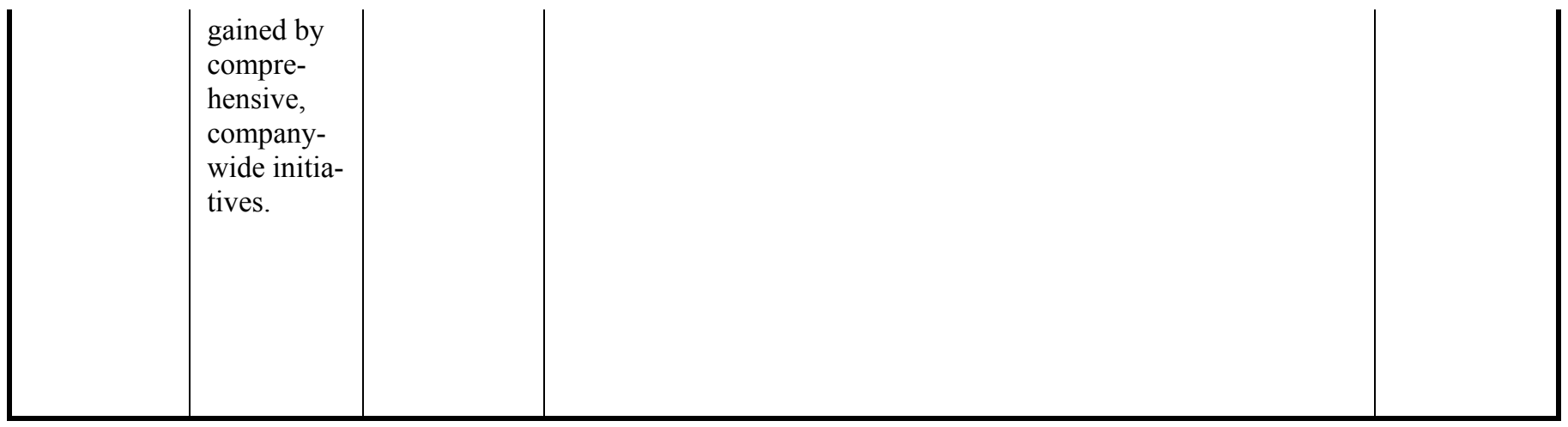

Fig. 1. Ergonomics Program Strategies [7]

\section{Company History}

\subsection{0s-early 1990s: Microergonomics}

The 3M E rgonomics Pro gram has fol lowed $t$ his typical progression of er gonomics program development. Specifi c ergonom ics technical e xpertise was added to the Industrial Hygiene Department in the early 1980s. For most of the next 10 years the focus was on raising awa reness am ong all em ployees and middle a nd upper $\mathrm{m}$ anagement o f er gonomics and evaluating a nd $\mathrm{m}$ aking i mprovements t $\mathrm{o}$ i ndividual workstations and equipment in response to employee reports of signs and symptoms of WMSDs.

\subsection{0s: Participatory Ergonomics}

The 3M Er gonomics Pro gram expande $\mathrm{d}$ i $\mathrm{n} t$ he early 1990s, a nd speci fic re quirements were established as part of the company's health and safety plan. At th e co rporate of fice, ad ditional erg onomists w ere hired, a nd a $\mathrm{n}$ erg onomics aware ness a nd technical training program was created and deployed at all US manufacturing locations. The expanded program had clearly defi ned e xpectations re garding e rgonomics for each US manufacturing location, a nd a form al ergonomics pr ogram and e rgonomics t eams were established. The ergonomics training was conducted by a cross-functional collaboration of corporate ergonomics, en gineering, occ upational m edicine an $\mathrm{d}$ industrial hygiene staff. The objective was to develop in-plant cap ability to id entify and reso lve ergon omics-related MSD injuries in the workplace. Costs and benefits were based upon reductions in workers com- pensation claims in the US. Technical expertise was provided by the corporate ergonomics staff.

There were positive results from this initiative and many improvements in w orkstation desi gn throughout the manufacturing locations. B etween 1990 and 2000 OSHA ergonomics reco rdable in juries were reduced by over $70 \%$ and lost-time cases reduce $d$ by $50 \%$. Additionally, th e av erage ergono mics-related workers com pensation claim cost was reduced by over $50 \%$, and lost-time claim costs reduced by $25 \%$. Awareness of ergonomics was in creased, but the location-based ergonomics $t$ eams were often c hallenged by frequent turnover and the lack of a uniform risk assessment tool.

\subsection{Since 2000: Transition to Macroergonomics}

In 2000, two events happened that set the stage for another program transition. First, a $\mathrm{M}$ anager of Ergonomics position was created. And sec ond, in response to OSHA's Ergonomics Standard, a th orough review was co nducted of the co mpany's pr ogram requirements and a survey of eac $\mathrm{h} \mathrm{m}$ anufacturing location was completed. The survey was developed to determ ine how well 1 ocations were implementing the program requirements in the following four categories:

- Ergonomics Written Program

- MSD Risk Management

- Ergonomics Expertise and Leadership

- Ergonomics Training

There were two key findings from the program review and implementation survey. First, the corporate program requirements were i dentified as being compatible with the OSHA Erg onomics Sta ndard re- 
quirement and $\mathrm{w}$ ould 1 ikely $\mathrm{m}$ eet $\mathrm{t}$ he st andard re quirements. Secon d, opp ortunities were identified for im proving th e co nsistency o f erg onomics $p$ rogram execution am ong the manufacturing locations. These two findings re sulted in a num ber of actions that have transformed the ergonomics program into a global program, fully implemented in over 180 locations, thereby setting the stage for $\mathrm{m}$ acroergonomics strategies.

The actions oc curred in two categories: technical changes and program changes. Techn ical activities included: identifying and adopting standard ergonomics risk assess ment tools; establishing dedicated and knowledgeable lo cation-based er gonomics r esources to conduct the risk assessments and identify and implement appropriate c ontrols; and c reating and making availab le nu merous erg onomics tr aining programs. Ergonomics was more closely integrated into the com pany's Environm ental Health and Safety (EHS) Man agement syste $\mathrm{m}$. Th is i ntegration included establishing and m easuring a c ompany-wide, five-year er gonomics goal that de fined performance expectations and i ncreased corporate ove rsight through a self-assessment system and participation in formal h ealth and safety au dits [8]. The following lists the tech nical too ls developed an $\mathrm{d}$ implemented during the past 15 years:

- 3M Intranet OfficeErgoHelp Website (1998)

- Ergonomics Solutions Database (1998)

- 3M Intranet Ergonomics Website (2003)

- Ergonomics Risk Analysis Tool (2003)

- Ergonomics Design Criteria Tool (EDC) (2005)

Program components include:

- Global Safety \& Health Plan Element (1996)

- Ergonomics Innovation Award Process (2000)

- Ergonomics Program (2001)

- Ergonomics Metric (2004)

- Ergonomics i n E ngineering Design C riteria Standard (2006)

\section{Management Commitment}

Establishing a management position to lead the ergonomics p rogram was one way the co mpany demonstrated commitment both technically and organizationally to ergonomics. The manager's position, by definition, $\mathrm{s}$ upports a $\mathrm{m}$ acroergonomics st rategy. The manager's responsibility is to : lead the development, coordination, and implementation of the ergo- nomics efforts at $3 \mathrm{M}$ locations worldwide; coordinate and manage work activities; identify ergonomics objectives and as sist locations in $m$ eeting those objectives through development of $\mathrm{p}$ rograms and asses sment tools; demonstrate im provements in employee well-being, production efficien cy, an d quality i mprovements; and c onduct governance nee ded to verify lo cations have ad equately met the company's ergonomics requirements. The management leadership position elevat ed e rgonomics orga nizationally to be on par with o ther env ironmental, health, an d safety programs. It also provided direct access to the Manufacturing E HS Committee, EHS Mana gers and Supervisors Leadership, and Engineering Council.

Ergonomics was also fully in tegrated i nto the company's E HS Mana gement System . This m eant ergonomics received the same oversight and visibility as the other environmental, health, safety, an d industrial h ygiene programs with in the co mpany. Oversight was conducted in three ways. Fir st, each location com pleted an annual self-assessm ent review, reporting $t$ he status o $f t$ heir erg onomics pr ogram. Second, ergonomics was i ncluded in the form al auditing process when conducted at manufacturing locations. And third, an EHS Scorecard measured progress toward an ergonomics goal.

\section{MSD Risk Management}

While successful, the sust ainability challenge s of training er gonomics tea ms conducted during the 1990s demonstrated the need for a rel iable and technically kn owledgeable e rgonomics reso urce at eac $h$ manufacturing location. Si nce the vast majority of manufacturing locations had fewer than 400 employees, hiring professional ergonomists at each location was not always feasible. However, each location did have a professional sa fety and/ or industrial hy giene resource. Our solution was to identify and standardize on one co mprehensive e rgonomics ri sk asse ssment tool that health and safety staff, as part of their formal job responsibility, could learn a nd accurately apply to i dentify erg onomics i ssues a nd i mplement effective s olutions. The E rgo J ob Analyzer (EJ A) was adopted as the required comprehensive MSD risk assessment to ol for use in all $\mathrm{m}$ anufacturing operations. 


\subsection{EJA Tool}

The EJA tool is based on information from leading ergonomics texts, resea rch reports, and c onference proceedings a nd is c omprised of 40 elements com monly asso ciated with MSD illness, in five general categories [1]:

- 1 medical-response element,

-2 excessive demands indicator elements,

- 32 body-part ergonomics-risk elements,

-4 environmental ergonomics-risk elements, and

- 1 cognitive ergonomics-risk element.

The asse ssment ris k-exposure $\mathrm{c}$ onclusions a re based upon observation a nd di rect m easurement of tasks performed, wh ich ar e th en co mpared to th e MSD risk exposure tables [1]. The risk tables categorize s pecific actions, such as carrying or bending, as high, moderate, low or OK MSD risk levels.

Based upon North American injury rates, a highrisk lev el ind icates a $1: 2$ probability of a medically related case o ccurring annually. Th us, in a high risk job there is a chance of one worker reporting a medically related case every two years. For moderate risk it is 1:5 and for low risk a 1:20 chance of an annual, medically related case. [1].

\subsection{Engineering Ergonomics Design Criteria}

The EJA Tool is applied to jobs being performed by em ployees. Ho wever, er gonomics gui dance for engineers while desi gning new e quipment was al so needed. T he solution was to translate the EJA risk exposure criteria in to Ergon omics Design $\mathrm{C}$ riteria (EDC) that e ngineers could apply during the design of new equipment. The criteria were adopted into the company's engineering design st andards. There are three primary advantages to having the sa me exp osure considerations. First, ergonomics risk exposure categories w ould be the sa me for new and existing equipment. Second, EJA-trained resources and engineers c ould more easi ly col laborate by ha ving a common "language" re garding ergo nomics. Th ird, communications ab out the r eduction of e rgonomics risk were bas ed upon the same criteria, all owing results to be more easily measured and communicated to management.

\section{Location Resources Development}

In support of the new Ergonomics Risk Reduction Process (ERRP), each location designated a health or safety person to become the EJA Resource, and c orporate estab lished an EJA t raining and certificatio $n$ process. The certification process is th e quality assurance that the EJA tool is used accurately to identify unacce ptable or hi gh ergonomics risk expos ure. Certification $r$ equires $\mathrm{k}$ nowledge of bi omechanics, physiology, an thropometry, and workstation desi gn through completion of online training, submission of homework, and final testing. The $\mathrm{n}$, at tendance at a three-day hands-on EJ A Workshop c onducted at a manufacturing location is required. At the workshop, attendees learn about and a pply the EJ A Tool and learn how to use measurement tools (e.g., force meters, goniometers, a nd pinch ga uges) a nd video to analyze jobs.

To complete certification, each EJA resource must submit evidence of acc urately co mpleted EJ As. Three jobs are su bmitted to th e co rporate staff fo $r$ review. Each job must include a co mpleted baseline EJA, risk exposure c onclusions, an d follow-up EJA verifying i mplemented $\mathrm{c}$ hanges we re ef fective. To assist the corporate staff $i \mathrm{n}$ the review, video of the job being performed is also provided. Certification is completed with the presentation of a $\mathrm{C}$ apstone Project. This presentati on summar izes o ne job im provement project a nd includes the baseline risk as sessment fi ndings, s olutions considered an d c hosen, cost/benefit a nalysis, and follow-up risk as sessment conclusions. The capstone projects a re presented at corporate-led ergonom ics e-m eetings, su pporting sharing of best practices throughout the company.

\section{Results}

It was unnecessary for every job in every manufacturing location to be analyzed using the EJA Tool [3]. The Company's ERRP pr ovided a framework to prioritize which jobs had the potential of una cceptable or high er gonomics r isk (Figure 2). The Potential High Risk Job Pool (PHRJP) works heet was created to $\mathrm{h}$ elp locations $\mathrm{p}$ rioritize a nd create action plans. Each lo cation co mpleted an in ternal PHR JP wo rksheet, created a list of existing jobs with the potential of ergonom ics-related ris $\mathrm{k}$, and $\mathrm{c}$ reated $\mathrm{t}$ heir own prioritization plan a nd i mplementation sche dule. Consideration was given $\mathrm{t} \mathrm{o}$ : $\mathrm{j}$ obs wi th a history of 
first aid or WMSD recordable cases in th e past two years; em ployee com plaints related to ergonomics; evidence of e xcessive job d emands through use of conditioning or st retching programs or job rotation; or jobs that the health and safety staff consid ered to be the physically hardest jobs in the plant. Each location was responsible for com pleting th e lo cation's PHRJP, an $d$ th e to tal $n$ umber of $j$ obs identified became th e lo cation's job improvement commitm ent for the five-year ergonomics goal.

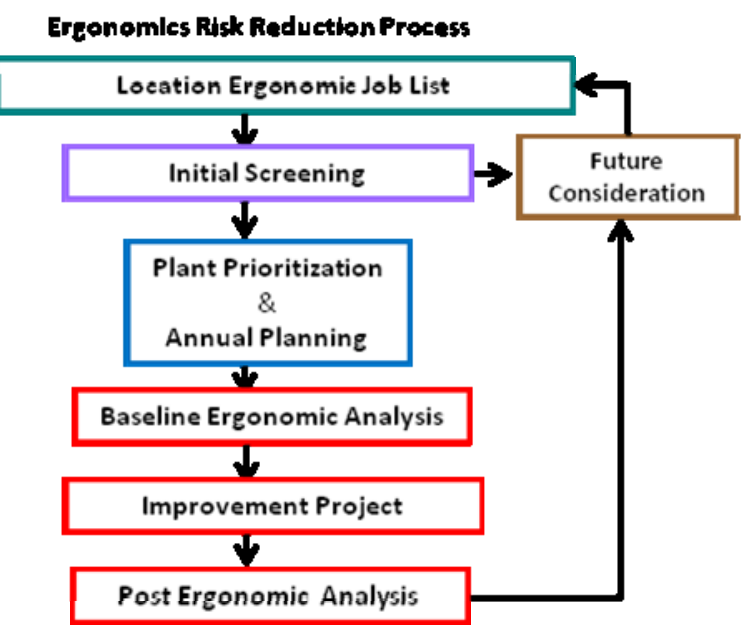

Fig. 2. Ergonomics Risk Reduction Process

\subsection{Five Year Ergonomics Improvement Goal}

In 2003, the company established a five-year ergonomics im provement goal $\mathrm{t}$ o reduce by $75 \% \mathrm{t}$ he highest risk WMSD ex posure by 2008 , as measured by the EJA T ool. T he number of targ eted jo bs for locations varied from 4 to 82 based upon the results of the location's PHRJP. And, based upon the location's $t$ argeted $j$ ob number, q uarterly per formance was m easured and reported on the company's EHS Scorecard.

\subsection{Results}

At the conclusion of the goal's 5-year period, $73 \%$ of the id entified highest risk ex posures were eliminated thro ugh i mplementation of a co mbination of work redesign, en gineering controls, and administrative controls. In US locations since 2004 at the start of the period, there has been a $55 \%$ reduction in the ergonomics case incide nt rat e, a $74 \%$ re duction in restricted-time case incide nt rate, and a $40 \%$ re duc- tion in lost-time cases in cident rate (Figu re 3) from the rates in the late 1990 s.

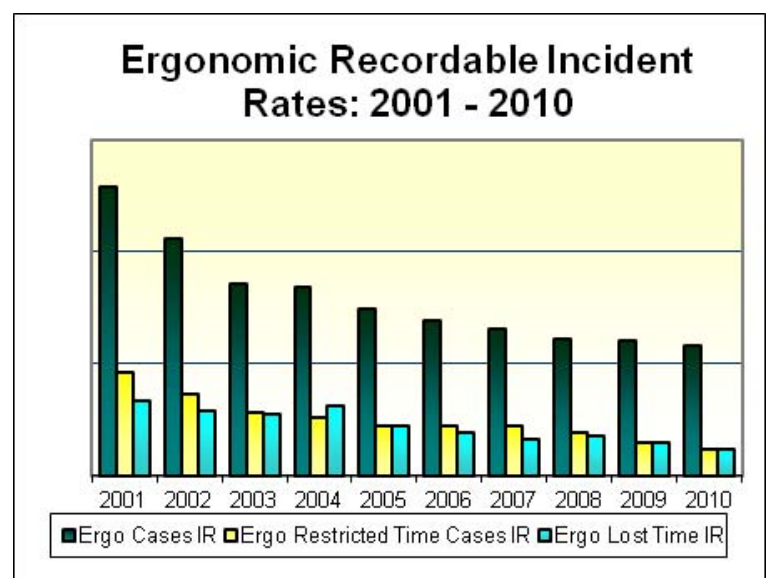

Fig. 3. Recordable Incident Rates from 2001 to 2010

\subsection{Ergonomics Award}

An i nternal com pany-wide Applied E rgonomics Innovation Award (AEIA) is a venue for sharing successful er gonomics improvements. The AEI A is an annual process $r$ ecognizing the most in novative and successful ergonomics improvements in three categories: Best New Eng ineering Design, Best Adaptation of an Ex isting Workstation, and Best So lution for Less than $\$ 1,000$. S ubmissions are judged by EJAcertified re sources and $\mathrm{c}$ orporate staff using the following criteria: risk reduction, inn ovation, su stainability an d replicability of solutions. Costs asso ciated with these award submissions break down into the following categories:

$\begin{array}{ll}\$ 0 & 33 \% \\ \$ 1-\$ 500 & 16 \% \\ \$ 501-\$ 1,500 & 13 \% \\ \$ 1,501-\$ 20,000 & 15 \% \\ \$ 20,001-\$ 40,000 & 13 \% \\ \text { Over } \$ 40,000 & 11 \%\end{array}$

Many $\mathrm{p}$ roject su bmissions include productivity, quality, or operatin $\mathrm{g}$ efficien cy im provement in formation. Over 500 award applications describing successful solutions a re posted on the company's in tranet EHS website and are available for all to reference. 


\subsection{Risk Assessment Data}

Over 2500 jobs have been analyzed using the standard job assessment tool. A detailed analysis of these jobs is b eing conducted. Th is an alysis will in clude: identification of sp ecific ergo nomics issu es by typ e of equipment and a better understanding of the correlation betwee $\mathrm{n}$ specific physical action and W MSD injury. Th is understanding will provide clarity as to which risk expos ures present the highest i mpact on employees' health and well being.

\subsection{Reflection}

3M's Ergonomics Program has evolved during the past 30 years. The summary provided in this paper is not a con trolled case stud y bu t is a representative case st udy of how one company's pr ogram t ransitioned from a microergonomics focus, responding to employee reports of discomfort and injury, to macroergonomics, integ rating the program in to asso ciated business objec tives. Results fr om th e er gonomics program cann ot be i solated from other internal business i nitiatives related to quality, $\mathrm{p}$ roduct development and production or isolated from external im pacts such as the global business climate. And ce $r$ tainly, th ese o ther ev ents also influ enced the results [13]. O $\mathrm{n}$ the ot her ha nd, the er gonomics pr ogram was s pecifically foc used on achieving thes e res ults and undoubtedly played a primary role .

\section{Conclusion}

The future of ergonomics in an y co mpany is dependent $u$ pon adding val ue to the c ompany. Thi $s$ study shows the added value ergonomics contributes to the company in improving employee well-being as demonstrated by the reduction of WMSDs. However, identifying the influence that ergonomics has on productivity and quality improvements as well as operating efficiency is possible and necessary for the longterm $\mathrm{v}$ iability of the program. A $\mathrm{m}$ acroergonomics strategy is essen tial to the long-term v iability of an ergonomics program and creates a value proposition beyond cost avoidance of WMSDs. Wh en be nefits are based solely on MSD illness redu ction, programs will eventually lose value and may even fail to maintain management support. Ergonomics must demonstrate ad ded value wh en i ncorporated i nto q uality, productivity, and efficiency initiatives.
Macroergonomics, by definition, em braces col laboration across and within business partners. This cross-functional collaboration demonstrates the value of a pplying e rgonomics kn owledge t o a part ner's own business objectives and builds value to business productivity a nd i mprovements i $\mathrm{n}$ operating e fficiency and quality. On ly then does ergonomics provide sustainable and significant value to business and become a core part of "how we do business."

\section{References}

[1] Aubur n Engineers, Ergo Job Analyzer User Guide, Auburn Engineers, 2003.

[2] Dul, J, Neu mann, W , Ergonomics contr ibutions to company strategies, Applied Ergonomics, 40, 2009, 745 - 752.

[3] GAO/H EHS-97-163 Worker Protection: Private Sector Ergnomics programs Yield Positive Results, Government Accounting Office, 1997.

[4] Haro, E, Kleiner, B Macroergonomics as an Organizing Process f or Syste m Safety, Applied E rgonomics, 39, 2008 450-458.

[5] Hendricks, H Apply ing Ergonomics to Sy stems: So me Documented "L essons L earned", Applied E rgonomics, 39, 2008 418-426.

[6] Herrera S, Huatuco, L, Human Factors and E rgonomics in Manufacturing \& Service Industries 21 (3), 2011, 227243.

[7] Larson, N, (2006). Macroergonomics in Global Cor porations "Going Gl obal" I n O. Brown Jr. and H. W. Henrick (Eds.), Human F actors in Orga nizational Design and Management - VIX.

[8] Larson, N, (2008). Macroergonomics in Global Cor porations "How to G et it Done" In O. Brown Jr. and H.W. Henrick ( Eds.), Human F actors in Or ganizational Design an $d$ Management-VIII.

[9] NIOSH Elements of Ergonomics Programs. 1997.

[10] OSHA Ergonomics Program Standard 19100.900, Occupational Health and Safety, 2000.

[11] 3M Internet http://www.3m.com, 2010.

[12] US Dept. of L abor Ergonomics Program Management Guidelines for Meatpacking, U.S. Depar tment o fL abor. OSHA 3 123, 1993

[13] Vink, P., Imada., A., Zink, K., Defining Stakeholder Involvement in Participatory Design Process, Applied Ergonomics, 39, 2008, 520 - 526 . 